HOW

Volume 29, Number 1, pages 37 - 63

https://doi.org/10.19183/how.29.1.623

How

\title{
Social Entrepreneurship Projects in the English Class: A Pandemic Multimodal Experience
}

Proyectos de Emprendimiento Social en la Clase de Inglés: Una Experiencia Multimodal en Pandemia

\author{
Jhooni Quintero-González ${ }^{1}$ \\ Amparo Clavijo-Olarte ${ }^{2}$ \\ Universidad Distrital Francisco José de Caldas, Bogotá, Colombia
}

\begin{abstract}
This exploratory qualitative study shares an innovative experience with twenty-three EFL undergraduate students in the Business Administration Program at a private university in Colombia. It aimed at positioning them as problem solvers and connecting their background as sources for EFL learning. We explored how business administration students problematized their communities to propose social solutions during the pandemic. Data were collected from students' reflective journals, students' artifacts, and a survey. In groups, the students explored cultural practices for shopping, economy, and pet-related issues to propose a social entrepreneurship project. Eleven business projects emerged as a result of students' socially-oriented concerns, critical skills, and multimodal experiences.
\end{abstract}

Keywords: communities, foreign language, multimodality, social entrepreneurship

He holds a B.A. degree in English teaching from Universidad Distrital Francisco José de Caldas. He is also a graduate student at the Masters' Degree in Applied Linguistics at Universidad Distrital Francisco José de Caldas. He is currently an EFL teacher at a private institution in Bogotá.

jaquinterog@correo.udistrital.edu.co

ORCID ID: https://orcid.org/0000-0002-0170-7396

She is a professor of Literacy at Universidad Distrital Francisco José de Caldas in Bogotá, Colombia. Her researcher interests are related to Community-based pedagogies and literacies in Language Teacher Education. Her current research project is on Literacies, cultures and pedagogy in Bogotá (LCPB).

aclavijo@udistrital.edu.co

ORCID ID: https://orcid.org/0000-0002-3752-7020

Received: October 17th, 2020. Accepted: October 13th, 2021.

This article is licensed under a Creative Commons Attribution-Non-Commercial-No-Derivatives 4.0 International License. License Deed can be consulted at https://creativecommons.org/licenses/by-nc-nd/4.0. 
Jhooni Quintero-González,

Amparo Clavijo-Olarte

\section{Resumen}

Este estudio cualitativo exploratorio comparte una experiencia innovadora con veintitrés estudiantes del programa de Administración de Empresas de una universidad privada en Colombia. Su objetivo es posicionarlos como productores de proyectos y conectar sus conocimientos previos como fuentes de aprendizaje del inglés como lengua extranjera. Exploramos cómo los estudiantes de administración de empresas problematizaron sus comunidades para proponer soluciones sociales durante la pandemia. Los datos se recogieron de diarios reflexivos y productos creados por los estudiantes, y una encuesta. En grupos, los estudiantes exploraron las prácticas culturales utilizadas para adquirir productos; prácticas problemáticas relacionadas con la economía y las mascotas para proponer un proyecto de emprendimiento social. Once proyectos empresariales surgieron como resultado de las preocupaciones de carácter social de los estudiantes, sus habilidades críticas y sus experiencias multimodales.

Palabras clave: empresariado social, comunidades, idioma extranjero, multimodalidad

\section{Introduction}

In the current Colombian EFL teaching and learning context, novel emancipatory and critical pedagogies are emerging. Consequently, it has been, and will be paramount for EFL teachers to orchestrate social action and critical reading of the world through critical literacy. Discourses are transmitted through language, and it structures the perception of individuals' milieu. Then, this awareness could lead to debunking the status quo (Janks, Dixon, Ferreira, Granville \& Newfield, 2014). Thus, we as teachers and teacher educators have the responsibility to walk students through endless possibilities for them to make sense of reality and enact changes within it. This article shares an exploratory research experience and a pedagogical project implemented with students in the business school at a private university in Bogota, Colombia, under the following lenses: critical literacies (Freire \& Macedo, 1987; Lewison, Flint, \& Slyus, 2002; Luke, 2012; Vasquez, Janks, \& Comber, 2019), multimodality (Kress, 2003; Jewitt, 2008, Walsh, 2010), and community-based pedagogy (CBP) (Sharkey, Clavijo \& Ramírez 2016, Moll, 1994; Demarest, 2015).

For the purpose of describing this research experience, this paper is written and assembled in four main segments. Firstly, in the needs analysis segment, we discuss the origin, guiding question, and rationale of the project. Secondly, the theoretical underpinnings supporting the framework for the pedagogical innovation will be discussed. Thirdly, we present the data collection instruments, the participants' profile, ethical considerations, and the main didactic choices made throughout the project in the methodology section. Then, we analyze and discuss the findings and learning outcomes derived from the pedagogical project aimed at a fruitful reflection. Lastly, we provide final remarks on the experience and personal reflection. 


\section{Needs Analysis}

In this section, we describe the setting and initial considerations for the pedagogical project. The implementation took place in a virtual class with twenty-three undergraduate EFL students of a private university located in the north of Bogota, Colombia. The students involved were in the program of business administration. They enrolled in the course English Level 4. English is a compulsory subject in all the degree programs offered at this university, and there are a total of seven levels (it varies depending on the program). Considering the institutional policies for EFL teaching that require teachers to follow an imported textbook (i.e., adopted foreign coursebooks) and students to obtain a good score on an international exam (Menken, 2006; Usma, 2009), we reflected upon the need to move away from a teaching paradigm focused on only results and proficiency (Ball, 2003) and start problematizing the approach to EFL teaching being used. We believe that language is not the end but the medium through which students access understanding of social concerns (Fairclough, 2001).

An academic dialogue initiated in February 2020, which continued throughout the academic year, nurtured our reflection between teacher practitioners and teacher educators. During the spring semester of 2020, when Jhooni enrolled in the critical literacy seminar offered by Amparo, she invited in-service teachers to get rid of deficit pedagogies that position students as passive learners and instead view them as active participants and coconstructors of their learning experiences valuing what Moll (1994) refers to, as funds of knowledge.

Thus, as university teacher educators and a teacher researcher, we decided to collaborate in the design and implementation of a more meaningful and context-responsive curriculum, considering students' needs, interests, and backgrounds through pedagogies of reconnection (Comber \& Kamler, 2004). We started conceiving ways to identify students' needs and interests by having students present their hopes, dreams, and ambitions as future businesses. Initially, the topic suggested was entrepreneurship. This subject matter bloomed out of a great number of the students claiming that they desired to set up their own business for economic independence as illustrated in the following excerpt: "I'm looking forward starting my own business" (Excerpt 1, Student A, April 4, 2020). Some of them were motivated by their family to help them economically (See Appendix A):

"I'd like to create a company with my father." (Excerpt 2, Student B, April 4, 2020)

"I would like to get to have my company where I can employ my family..." (Excerpt 3, Student C, April 4, 2020)

This initial exploration with Jhooni's students helped us think of an approach to social entrepreneurship, in which the students could explore the marketing strategies to identify needs in order to start a business with the purpose of empowering them as critical subjects 
Jhooni Quintero-González,

Amparo Clavijo-Olarte

in relation to their careers. Thus, we posed the following research question: How do business administration students problematize their communities to propose social solutions during the pandemic? As a result of this decision, the topic of social entrepreneurship was proposed as a curricular project for all students in the program. This concept has multiple definitions, since it comprises a lot of characteristics. Thus, the definition that we adopted views social entrepreneurs as agents of social change through the establishment of an enterprise that is the result of innovation. Furthermore, we consider that social improvement is predominant over profit maximization (Huybrechts \& Nicholls, 2012). This concept, as opposed to mere entrepreneurship, paves the road to collective social enhancement (Chell, 2007).

Consequently, the business administration students were invited to explore the culture of social entrepreneurship to be able to come up with a business idea based on their interests and the market analysis within the COVID-19 emergency. The students expressed their interest in participating in the project. The process of problematizing and rethinking one's own teaching in the critical literacy seminar guided by Amparo was informed by professional readings proposed by and in interactions with her along with critical reflections on the topics proposed by the students for their social entrepreneurship project. Selecting theoretical sources as foundations that support this exploratory study was also a collaborative project for us. Our common interest in social entrepreneurship to impact communities, critical literacy, and local knowledge was a meeting point for the discussion. Hence, an academic discussion about the theoretical underpinnings follows.

\section{Theoretical Underpinnings}

\section{Community-Based Pedagogy for EFL Learning}

One principal cornerstone conceived in this exploratory research experience is community-based pedagogy (CBP henceforth). CBP has been utilized in an array of studies and has been theorized by a good number of authors internationally and locally (for instance, Moll, 1994; Azano, 2011; Demarest, 2015; Medina et al., 2015; Sharkey et al., 2016). In this section, we discuss selected authors and pedagogical experiences concerning this framework, which helped reach a purposeful definition that guided the project with the students. Firstly, one insightful contribution to this field is the concept of funds of knowledge by Moll (1994). The author claimed that this term within a sociocultural perspective is linked to the premise that a student is deeply connected to social aspects and practices that embody intellectual resources for learning. Hence, those funds can be successfully used for classroom instruction. Having mentioned this, we kept in mind the students' previous and sociocultural experiences to be able to exploit their potential in the learning process. 
Another pivotal perspective in CBP is the link between pedagogy and place. As suggested by Demarest (2015), one's identity is related to the place one belongs to, thus, it entails an understanding of life. This notion comprises a wide range of views to consider when creating curriculum, hence, the concept of local knowledge becomes central as "it's a term that helps us understand the diverse experiences of students and the particular aspects of their lives" (Demarest, 2015. p. 9). This reasoning behind local knowledge has been a paradigm for many researchers. For instance, Azano (2011) investigated how a teacher made use of places to teach eighth graders in a rural school in the U.S. The researcher found that place-based pedagogy could be a significant entry point for teachers to better activate prior knowledge and make more meaningful connections to curriculum.

In the Colombian context, there have been profound contributions to CBP, with a broader scope. This is the case reported by Medina et al. (2015). The researchers carried out an investigation in an online-based EFL course in a public university with undergraduate students from different programs. Medina et al. (2015) analyzed how students read the community critically in an EFL online course. The findings demonstrated that the students recognized the community assets and used them as resources. Also, the participants read the community critically from a problem-solving perspective in order to find solutions that responded to the troublesome issues of the context. One conclusion stated was the necessity for teachers to break the dichotomy between school and community. This is grounded evidence of the idea that local knowledge within a CBP approach can widen the scope and contribute to valuing what the community has to offer and take it as a resource for the EFL learning and teaching.

In another study, Sharkey et al. (2016) looked into the work and points of view of four public school teachers during the implementation of CBP. The authors claimed that the benefits of this approach are an increase in the students' engagement, motivation, family participation, and appreciation of local knowledge. Sharkey et al. (2016) gave evidence that $\mathrm{CBP}$ can be used as practices within a curriculum. Local knowledge and community are assets for teaching and learning; nonetheless, the authors account for the compliance with standards that teachers must handle.

The aforementioned theoretical tenets deem CBP as a means of creating curriculum while considering different viewpoints such as students' socio-cultural backgrounds, context, community resources, and knowledge from their professional discipline for achieving learning, teaching, and standards goals, and most importantly, students' needs and interests. In addition to this view, there is an intertwined component, which is critical literacy. The consideration of community and its particularities, apart from serving the purpose to enhance learning and teaching in the EFL setting, also has the function to develop an analytical perspective towards the world (Freire \& Macedo, 1987). One must be mindful that the world is loaded with discourses that shape our identities (Gee, 1996; Benwell \& Stokoe, 2006), and this 
Jhooni Quintero-González,

Amparo Clavijo-Olarte

entails social transformation as those messages are redesigned to create knowledge (Janks, 2012). Thus, this transition of debunking the taken-for-granted viewpoint is guided by the comprehension of sociopolitical issues (Freire \& Macedo, 1987; Lewison et al., 2002; Luke, 2012; Vasquez et al., 2019) leading to agency within one's community.

This practice of critical literacy as an overtly political act in the classroom has been widely applied in education. As an example, Batista-Morales, Salmeron, and Dejulio (2019), using a case study methodology, presented how bilingual students from a local school in the U.S. engaged in social transformation using critical-literacy instruction led by pre-service teachers. This study provides valuable insights into the transformation that can be enacted from the classroom. Another example is the implementation carried out by Gil (2018). The author, through a qualitative study, utilized critical literacy to unveil how ten senior students' practices informed their concern for social issues. Gil (2018) presented her students' own interest in becoming social agents to change their worlds.

This study considers the introspection process that students went through in order to position themselves as active participants of the world. Thus, it is evident how the grasp of socio-political and cultural issues relying on funds of knowledge can be resources in the EFL classroom to promote pertinent and context-based social change. Our intention throughout this exploratory research and pedagogical project is to foster emancipation and critical view of the world among students as future business leaders.

\section{Digital Literacies and Multimodality as Tools}

A relevant situation that must be considered in the development of this project is the fact that it began within a pandemic. This required an online adaptation of classes. This abrupt and sudden virtualization led to other types of considerations in the project, in addition to the abovementioned ones. Owing to such worldwide emergency, the coordinators provided the students and professors at the university with tools to carry out lessons by using Microsoft Teams and useful apps available on the same widget. First, this hasty shift involved a process of online exploration of tools to develop lessons; second, EFL students also needed to adapt to the new technologies (Walsh, 2010).

A salient angle to reflect on is the use of digital multimodal texts. Even though there has already been a necessity to extend semiotic resources in the classroom for students' and teachers' use (Janks, 2010, as cited in Vasquez et al., 2019), in this teaching context, the mobility to an online world became prominent given the circumstances. Kress (2003) argued that "the book has now been superseded by the screen in the role of dominant medium of communication - using screen as a shorthand term for the new communication and information technologies" (p. 12). Considering this point of view, we see that isolating 
literacy practices from the digital world given the massive array of social, technological, and economic factors is hardly possible (Kress, 2003).

Considering the nature of this innovative project under pandemic circumstances, we draw on the multiple digital modes to construct knowledge. According to Jewitt (2008), the basic assumption to multimodal perspectives is the construction of meanings through many representational and communicative resources. In a study carried out by Walsh (2010), the author discussed evidence as to how sixteen teachers implemented printed-based literacy along with digital communication technology. Walsh (2010) claimed that literacy education needed to be redefined within current curriculum contexts and teachers' awareness of the digital communication practices. Thus, multimodal practices are intensified by digital technologies (Lotherington \& Jenson, 2011, as cited in Medina et al., 2015). Considering the above-mentioned circumstances of remote teaching, we can see that this exploratory research aimed at making use of the possibilities offered by digital literacies and its multimodal texts for students to construct knowledge of their own worlds.

As the project aimed to examine how business administration students problematized their communities to propose social solutions during the pandemic, this research sought to unveil how students problematize the dynamics of their communities. Also, the intention of the study was to identify learning implications in EFL students when they were engaged in community-based pedagogy and foster EFL learning using varied semiotic resources. Thus, in the next section, we provide a description of the methodology employed to accomplish the above objectives.

\section{Methodology}

This qualitative exploratory research project, informed by critical literacies and community-based perspectives that value local and community resources for teaching, proposes a pedagogical transformation aimed at creating social entrepreneurship projects with university EFL students. In the professional literature, exploratory research is conducted to achieve a better understanding of an existing problem, but usually does not lead to a conclusive result. Researchers use exploratory research to gain familiarity with an existing phenomenon and acquire new insights into it to form a more precise problem. For Heigham and Croker (2009), qualitative research is useful because it is exploratory; it mostly focuses on understanding the particular and the distinctive and does not necessarily seek or claim to generalize findings in other contexts. Additionally, Rossman and Rallis (2003) consider that "A ... feature of qualitative research ... is a reliance on sophisticated reasoning that is multifaceted and iterative, moving back and forth between the parts and the whole" (p. 47). 
Jhooni Quintero-González,

Amparo Clavijo-Olarte

\section{Participants}

As stated in the needs analysis above, the participants in the study consist of $23 \mathrm{EFL}$ undergraduate students in the Business Administration Program at a private university in Bogota, Colombia. Their ages ranged from 18 to 47. They were senior students in their seventh academic semester of the major. Out of 23, 19 students signed the consent forms and granted us permission to use their real names in the article and utilize the data collected in the EFL class for analysis and publication purposes.

\section{Instruments}

We collected data through three main instruments: reflective journals, students' artifacts, and a survey. Reflective journals invited the participating students to write responses to a guiding question that aimed at provoking reflection during the five weeks of the project. The question 'What aspects of the community are important for my company?' generated responses that evolved during the students' inquiry and implied further reflections and understandings about people's needs towards different products within the situational changes emerging from the pandemic.

In groups of three, the students worked on putting ideas together to create their company. The final outcome was shared with the whole class through a poster that presented their 11 business ideas (see Table 1 in the section of Data Analysis and Findings). They used different free applications available such as Photoshop, Adobe Spark, and Canva to portray their business ideas. A final survey was used to gather their perceptions about how this project contributed to their professional and personal growth, in addition to their proficiency in the English language.

The following section provides details about the pedagogical and curricular choices negotiated with the students during the implementation of the project. There were rich dynamics within the groups throughout the design of the project.

\section{Reading the World under Critical Lenses:}

\section{Our Curricular Proposal}

The curricular project was developed under critical reading of the world to achieve social awareness in the EFL classroom. The curriculum proposed is founded on inquiry principles. As stated by Short and Burke (1991), curriculum as inquiry contains beliefs that support how learning is achieved: (1) Learning is inquiry and vice versa, (2) Inquiry questions are posed by all the participants in the inquiry, (3) Trust allows a continuance of engagement in inquiry; finally, (4) Exploration is paramount to engaging in inquiry. These 
beliefs guided the curriculum applied in this pedagogical experience since they positioned the participating students as authors of their own worlds and experiences, and, at the same time, positioned teachers as learners of those contexts (Luke, 2012). Additionally, we walked the students through a five-week scaffolding process to provide them with the tools to design their business idea. In this curriculum, we utilized the six scaffolding strategies proposed by Walqui (2006) (See Figure 1 below).

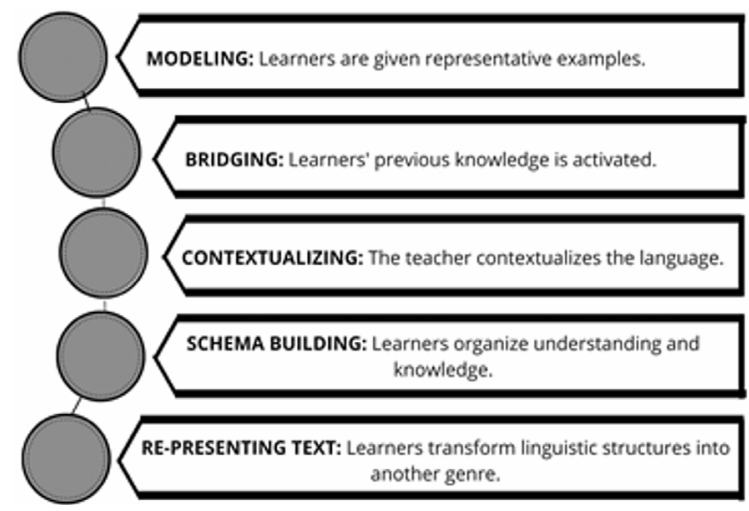

Figure 1. Scaffolding Strategies by Walqui (2006)

In consideration to this framework, the following Figure 2 summarizes the implementation.

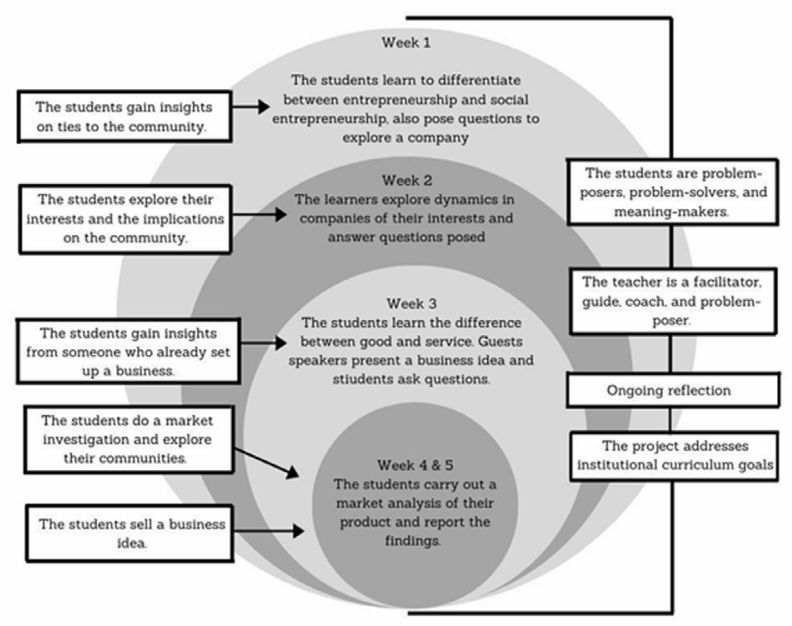

Figure 2. The Implementation Process 
Jhooni Quintero-González,

Amparo Clavijo-Olarte

Throughout the process presented in the above Figure 2, students explored a wide range of websites, tools, and widgets. To explore, investigate, and present findings, the participating students used programs such as Prezi, Microsoft Power Point, social networking sites, YouTube, Classtools.net, and websites just to name a few. The students were actively involved in the design and production of texts that were the result of other texts analyzed (Vasquez et al., 2019). Jhooni's role as the classroom teacher came along as "a coach, problem-poser, and facilitator" (Demarest, 2015, p. 5). The students were provided with guiding questions, but also, they posed their own questions.

Furthermore, during the entire implementation, students were provided with feedback and ideas to do research on their communities. Following their process of creating their own business as social entrepreneurs, the students presented their business ideas in the last class; this presentation contained much of the insights that they had gained during the project. In the following lines, we analyze the data gathered based on their reflective journals, artifacts, and a survey. This is possible, considering that they comprised the complete set of appreciations in the inquiry.

\section{Data Analysis and Findings}

As mentioned earlier, the participating students were invited to create their own business projects with a social purpose and integrating the community resources available. We observed that most of the students developed a sense of place, which means they developed the ability to closely observe and analyze their landscapes (Demarest, 2015) for the purposes of creating their business. In order to demonstrate this hypothesis and to respond to the objectives set at the beginning of this project, we analyzed the data gathered in the students' artifacts (e.g., Word documents, Microsoft PowerPoint presentations, oral presentations, comments, posters, and chat lines), the students' reflective journals, and a survey. In total, there were 11 projects; therefore, the data resulted in a vast array of outcomes (See Table 1 below)

Table 1. Students' Business Ideas

\begin{tabular}{|l|l|}
\hline Business idea & \multicolumn{1}{|c|}{ Description } \\
\hline Vives Coffee & $\begin{array}{l}\text { This project was based on the idea of selling } \\
\text { coffee from Guayabal de Siquima. }\end{array}$ \\
\hline Stock App & $\begin{array}{l}\text { An app that allows users to find nearby } \\
\text { supermarkets and to separate food for pick up. }\end{array}$ \\
\hline
\end{tabular}




\begin{tabular}{|c|c|}
\hline Business idea & Description \\
\hline 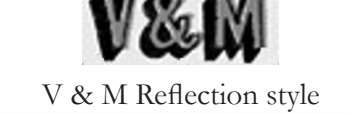 & This project was intended to sell decorations for the house. \\
\hline $\begin{array}{c}\text { PI STORE } \\
\text { MAKUNA } \\
\text { MATATA } \\
\text { Pet Store \& Hakuna Matata }\end{array}$ & These ideas were about pet accessories and pet food. \\
\hline Mader & $\begin{array}{l}\text { This app was thought to help carpenters and prospective } \\
\text { customers connect for carpentry services. }\end{array}$ \\
\hline Little Fast Picadas & $\begin{array}{l}\text { This idea was intended to sell fast food to } \\
\text { local customers in their neighborhood. }\end{array}$ \\
\hline Feed your Dog & This project was based on a vending machine for pet food. \\
\hline $\begin{array}{l}\text { Farlasty } \\
\text { Zowts. } \\
\text { Fantasy Tours }\end{array}$ & $\begin{array}{l}\text { A travel agency intended to help to activate } \\
\text { the economy after the pandemic. }\end{array}$ \\
\hline Chef's Delicacies & It was a business to sell desserts. \\
\hline $\begin{array}{c}\text { Industraf DI } \\
\text { MEDICAL } \\
\text { Industrial DI Medical }\end{array}$ & $\begin{array}{l}\text { The idea was based on the necessity of people } \\
\text { to wear masks. The main purpose was to sell } \\
\text { surgical masks at a reasonable price. }\end{array}$ \\
\hline
\end{tabular}


Jhooni Quintero-González,

Amparo Clavijo-Olarte

In the process of exploring the community, finding information, making decisions, and getting involved in their projects about their community, the students genuinely engaged in a multimodal experience. To carry out the project, the students made use of an array of digital tools to illustrate their work. The amount of data implied that the students went through a process in which digital tools served as mediators to visually represent the products and services their businesses could offer. Therefore, varied sources such as videos, articles, websites, and apps, among others, were explored and employed in order to support their insights. Thus, the semiotic resources available came in handy for them not only to cope with the difficulties of the COVID-19 emergency but also to engage in a multimodal experience.

As presented in Table 1 above, the students' business ideas were about the following products or services: Surgical masks, two cellphone apps, marketing coffee, decorations, bakery products, fast food, two pet-store products, pet food and accessories, and a travel agency. In their own ways, they explored different issues related to people's needs in their communities. Considering the data gathered, we relied on Miles and Huberman's (2000) steps on data management and analysis. This process implied data collection, data reduction, data display, and conclusions: data presentation. The information was organized in a matrix where we identified salient categories. The following Table 2 summarizes how the students problematized their communities to propose social solutions during the pandemic.

Table 2. Main Categories

\begin{tabular}{|c|l|c|}
\hline Research question & $\begin{array}{c}\text { Problematic issues in the } \\
\text { community }\end{array}$ & Category \\
\hline \multirow{3}{*}{$\begin{array}{c}\text { How do business administration } \\
\text { students problematize their }\end{array}$} & - Online vs. in-place shopping. & Cultural practices in shopping \\
\cline { 2 - 3 } communities to propose social & - Price gouging. & \\
solutions during the pandemic? & pandemic restrictions. & Economic issues \\
& - Tourism economic crisis. & \\
\cline { 2 - 4 } & - Pets being abandoned. & \\
& - Pets labeled as a source & Pet-related cultural issues \\
& of virus spread. & \\
\hline
\end{tabular}

The examples in the following subsections have been chosen since they contain a rich variety of data that not only answered the research question but also captured the representativeness of the categories in Table 2 above. 


\section{Cultural Practices in Shopping}

Several of the participating students explored people's shopping habits during the pandemic (e.g., Mader App, Little Fast Picadas, and Industrial DI Medical). As an example, Christian, Carolina, and Elizabeth proposed Stock App. It was an application intended to allow shoppers to search for nearby products and have them packed and ready to go, so they could pick them up without lining up. They remarked that due to the capacity restriction in public places set by the government, many times people waited for so long to go into a supermarket only (See Appendix B) to realize that the product was sold out: "Example, my mom had to stand in a long line to go to the market, and she go to the supermarket, there were no products" (Excerpt 4, taken from Carolina's group oral presentation, May, 30th 2020). [sic]

The students stated that this situation would not contribute positively to the pandemic situation as more people would pile up leading to more people infected with the virus. The students looked at the issue of people not wanting to buy online and suggested that clients could have the products ready to go so the customer could see the product without walking about the store to pick up the item; therefore, avoiding the risk of spreading the virus. This piece of evidence shows how the students suggested possibilities for improvement in the community (Vasquez et al., 2019).

Another illustrative example is Mader App. Kelly and Luisa proposed an application to help local carpenters in Soacha to connect with clients to sell their products (See Appendix C). According to the students, the app would serve as a bridge between carpenters who have been affected by the pandemic restrictions and customers who need comfortable furniture with which to work from home. Kelly and Luisa interviewed carpenters to give evidence of the need that they had to show their products and be able to work:

"Luisa: Would you be willing to be part of Mader App?"

"Interviewee: Yes, because we've been forced to close our shops to the public and it's been difficult to sell as nobody is allowed to go out. Also, people are using technology to buy more than ever before." (Excerpt 5, My translation, taken from Luisa and Kelly's interviews. April, 2020)

The main idea was to have pictures of furniture displayed in the app so as to create the contact between customer and carpenter to quote products at a distance. Both examples Stock App and Mader App explored cultural shifts in practices when shopping due to the COVID-19 situation. Students got involved in their communities exploring different situations where the issues identified impacted their community's culture shopping practices. However, they not only pinpointed these problematic situations but also started to propose possible solutions through their business ideas in English class. 
Jhooni Quintero-González,

Amparo Clavijo-Olarte

\section{Economic Issues}

A couple of groups unveiled economic issues, and this inspired them to think about business ideas that could help improve the situation (e.g., Fantasy Tours, Industrial DI Medical, and V \& M Reflection style). In order to exemplify this theme, we rely on Vives Coffee. Miguel and Viviana's idea had to do with the coffee business in their region. Their experiences became narratives of their family history as coffee growers that justify their social entrepreneurship. Viviana stated that she was originally from Guayabal de Siquima, a small town in the state of Cundinamarca, Colombia. She was interested in talking about their hometown and the different kinds of coffee there were (Sharkey et al., 2016). Miguel had also been thinking about the feasibility as he expressed how cheap it would be to start a factory of coffee there. When they presented their business idea, they stated that the coffee growers in Guayabal de Siquima were badly paid by middlemen. Given this fact, the middlemen would buy cheap and later make a great profit selling it in the city (See the following excerpts from the students' artifacts).

\begin{tabular}{|l|l|}
\hline \multicolumn{2}{|c|}{ A fair payment without middlemen (Students' artifacts 1, April, 2020) } \\
\hline $\begin{array}{l}\text { Yes, because Viviana's parents and } \\
\text { neighbors have been coffee producers } \\
\text { for many years, sales are favorable and } \\
\text { if the business is strengthened and } \\
\text { without intermediaries, it would favor } \\
\text { the producing community, and coffee } \\
\text { is also a product that is exported and } \\
\text { well received at the national level. }\end{array}$ & $\begin{array}{l}\text { https://www.larepublica.co/consumo/ } \\
\text { las-liendas-de-cafe-cambiaron- }\end{array}$ \\
\hline $\begin{array}{l}\text { We seek to generate employmen-cuarenta-anos-al- } \\
\text { and regarding production, we } \\
\text { seek that the farmer receives a } \\
\text { fair payment and increases the } \\
\text { potential of his productive work. }\end{array}$ & \\
\hline
\end{tabular}

The students illustrated that problem by using a WhatsApp audio from Viviana's father. In their proposal, they manifested the feasibility of the product appreciating the properties of the land, the knowledge of the local coffee growers and the culture of people with a fondness for coffee (Moll, 1994) (See Appendix D). These students were able to bring into the classroom an issue concerning Viviana's community in Guayabal de Siquima (Freire \& Macedo, 1987). They problematized Viviana's father's unfair trade to sell coffee (Medina et al., 2015; Lewison et al., 2002, Luke, 2012). 
One more example of this category is in Luisa and Daniel's business proposal. They were the authors of Industrial DI Medical. This pair stated that the pandemic has affected the residents of Kennedy due to the emergency restrictions issued by the mayor's office in Bogotá. According to these students, this situation has led to price gouging and economic recession in the sector. See the following excerpt from the students'artifacts:

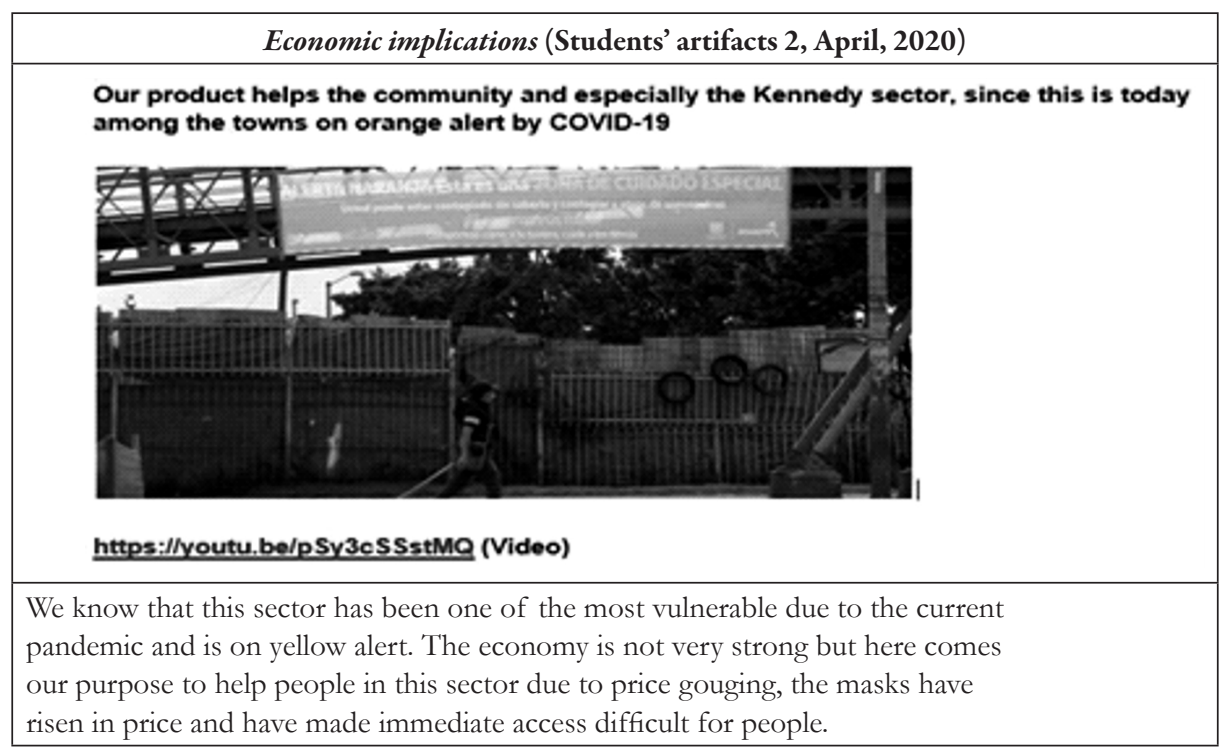

The students stated that they could manufacture cheaper facial masks as a family relative of theirs had experience making them. In the above projects, the groups exemplified how some economic issues became a salient point of discussion due to the pandemic emergency in the country.

\section{Pet-Related Cultural Issues}

There were a considerable number of students concerned with pet-related culture treatment (e.g., Hakuna Matata and Feed your Dog). For instance, Maria and Catalina worked on a project related to a pet store in Chapinero, a traditional neighborhood in Bogota, Colombia. These students' business idea consisted of establishing a place to sell all kinds of pet accessories (See Appendix E). They carried out interviews in the market-research analysis they did. They asked interviewees what practices they had identified that people do because of the pandemic; they found out that dogs were being abandoned:

"Maria: How do you think dogs have been affected by the coronavirus issue?" 
Jhooni Quintero-González,

Amparo Clavijo-Olarte

"Interviewee: Due to the pandemic, eh... many people are experiencing lack of knowledge, they believe that they are a source of contamination and they abandon many of them." (Excerpt 6, taken from Maria and Catalina's interviews. April, 2020)

In addition, they showed the importance that pets have in people's lives. They relied not only on the interviews, but also on news on the internet to support these practices. Maria and Catalina expressed that they would like to contribute to the situation; hence, they looked on Instagram for accounts that helped stray animals. They reported what to do in case someone found a pet in need by using this account.

In the same vein, Yised and Julian, whose business idea was Hakuna Matata, coincided with Maria and Catalina's findings. They also found that pets were being abandoned due to people's fear of getting infected with COVID-19, and also because people did not have enough money to take care of them considering the economic recession caused by the same pandemic. This group relied on online news from different sources to support their claim (See Appendix F). This group proposed to establish a network with other people interested in helping stray animals in two ways: First, they could spare a small amount of pet food for any stray animal passing by when customers buy food. They proposed they could encourage clients to donate a small percentage of what they buy for this purpose. Second, they could create a social networking group in order to help stray animals relocate:

"With people having all sorts of information on apps such as: Instagram, Facebook and many others. We create another group dedicated to posting pictures with information of pets needing a new owner. There are people looking to help." (Excerpt 7, taken from Yised's oral presentation, May, 30th 2020).

In this section, it was our intention to display the major themes extracted from the data analysis (Miles \& Huberman, 2000) to shed light on the way the business administration students problematized their local realities from a socio-critical perspective (Freire \& Macedo, 1987) in order to propose social solutions during the pandemic. It is relevant to point out that CBP (Moll, 1994; Demarest, 2015) played a relevant role in the students' empowerment to intertwine their EFL learning and their immediate community practices under pandemic circumstances. The problematization led by their authorship positioned them as critical readers and solvers (Demarest, 2015) of their own reality.

\section{Discussion}

As revealed in the previous lines, the participating students could observe and problematize their context by engaging actively in the exploration process. They first began reading about the dynamics in companies of their interests. The students identified if companies were tied to the community and the ways they served the community. This process led them to ponder other aspects within companies' practices that, as they expressed, 
had never been exposed. For example, Harold (a student) expressed that his view about his career had merely served monetary purposes up until this project.

The students developed a new understanding about the concept of social entrepreneurship through their collaborative experience and became problem-posers and problem-solvers of their immediate context in this pedagogical innovation (Demarest, 2015). Thus, they investigated how the pandemic has changed people's practices on different levels and thought of possibilities to enact changes considering those issues. This was aided by relying on and acknowledging local knowledge (Demarest, 2015) and on immediate community assets (Moll, 1994; Medina et al., 2015; Sharkey et al. 2016) through the use of multimodal texts on an online setting (Kress, 2003, Jewitt, 2008; Walsh, 2010).

Furthermore, we point out that the route paved for students to get involved in their community was possible through the inquiry and scaffolding process. As the intervention was being implemented, students were provided with tools to start problematizing those dynamics with which they were concerned. Furthermore, EFL instruction was ubiquitous throughout the curriculum. Students, in the different activities, made use of the target language. They expressed that the project contributed to their personal and professional lives and the activities were interesting and allowed them to practice all the abilities in a context of their interest (See Appendix G).

\section{Conclusions}

In this exploratory project, we posed the question 'How do business administration students problematize their communities to propose social solutions during the pandemic?' Throughout the study, we could see that the students transformed themselves into inquirers of their own reality in the EFL classroom. They acknowledged the assets of their communities and were able to pinpoint immediate issues in their context in three major categories: cultural practices for shopping, coffee economy, and pet-related cultural issues. In addition, they not only discovered those problematic situations within their milieu, but also suggested ideas context-responsive and practical solutions through their businesses. Moreover, this study turned out to be developed under two scenarios: a virtual classroom and a pandemic considering the COVID-19 emergency.

During the entire study both the students and the teacher researcher went through a virtualization process that allowed them to cope with teaching and learning difficulties that were part of the health emergency globally. Hence, both the teacher and the students engaged in a multimodal experience as they utilized the different semiotic resources, available online, as a means to convey and create meaning in the target language. The study also served the students' needs in regard to what was meaningful for them as it was interwoven with their 
professional field. It is pivotal to argue the necessity to position EFL students, regardless of their backgrounds, as socio-critical thinkers and accountable in todays' society despite any adversity that may arise.

It was a fruitful experience bearing in mind the insightful lessons provided by the collaboration between a teacher researcher and a university teacher educator. It provided an opportunity to implement a more pertinent and context-responsive approach to EFL teaching and learning. Furthermore, this experience paved the way to revise a pedagogical approach that responded to top-down institutional policies, and instead plant this emancipatory paradigm through which the students generated social entrepreneur projects that responded to their personal and professional interests. Feeding this new perception, as well as continuing to utilize the vast array of resources and assets from our local context, is meaningful.

An important consideration under these critical lenses in pedagogy is the type of power relations that have emerged in the EFL world. Most of the time, as English language teachers, we get absorbed by discourses that do not contribute to our teaching practice; on the other hand, they continue to indoctrinate us into passive and submissive ways of teaching. These critical perspectives allow us to take up creating and employing more pertinent pedagogies.

\section{References}

Azano, A. (2011). The possibility of place: One teacher's use of place-based instruction for English students in a rural high school. Journal of Research in Rural Education, 26(10).

Ball, S. (2003). The teacher's soul and terrors of performativity. Journal of Education Policy. Taylor \& Francis group. 18(2), $215-228$.

Batista-Morales, N. S., Salmerón, C., \& DeJulio, S. (2019). Their words, their worlds: Critical literacy in bilingual spaces, Bilingual Research Journal, 42(4), 471-490.

Benwell, B., \& Stokoe, E. (2006). Discourse and Identity. Edinburgh University Press.

Chell, E. (2007). Social enterprise and entrepreneurship: Towards a convergent theory of the entrepreneurial process. International Small Business Journal, 25, 5-26.

54 Comber, B., \& Kamler, B. (2004). Getting out of deficit: Pedagogies of reconnection. Teaching Education, 15(3), 293-310.

Demarest, A. B. (2015). Placed-based curriculum design. Exceeding standards through local. Taylor and Francis group.

Fairclough, N. (2001). Language and power. Pearson Education.

Freire, P., \& Macedo, D. (1987). Reading the word and the world. Greenwood Publishing Group, Inc.

Gee, J. P. (1996). Social linguistics and literacies: Ideology in discourses. Taylor \& Francis. 
Gil, L. (2018). Critical literacy development in an EFL classroom [Unpublished Master's thesis]. Universidad Distrital Francisco José de Caldas. Bogotá, Colombia.

Heigham, J., \& Croker, R. A. (2009). Qualitative research in applied linguistics: A practical introduction. Palgrave Macmillan.

Huybrechts, B., \& Nicholls, A. (2012). Social entrepreneurship: Definitions, drivers and challenges. Routledge.

Janks, H. (2012). The importance of doing critical literacy. English Teaching and Critique, 11(1), 150 163.

Janks, H., Dixon, K., Ferreira, A., Granville, S., Newfield, D. (2014). Doing critical literacy. Routledge, https://doi.org/10.4324/9780203118627

Jewitt, C. (2008). Multimodality and literacy in school classrooms. Review of Research in Education, 32(1), 241-267.

Kress, G. (2003). Literacy in the New Media. Routledge.

Lewison, M., Flint, A. S., \& Van Sluys, K. (2002). Taking on critical literacy: The journey of newcomers and novices. Language Arts, 79(5), 382-392.

Luke, A. (2012). Critical literacy: Foundational notes. Theory Into Practice, 51(1), 4-11.

Medina, R., Ramírez, M., \& Clavijo, A. (2015). Reading the community critically in the digital age: A multiliteracies approach. In P. Chamness Miller, M. Mantero, \& H. Hendo (Eds.). ISLS Readings in Language Studies (Vol. 5) (pp. 45-66). The International Society for Language Studies, Inc.

Menken, K. (2006). Teaching to the test: How no child left behind impacts language policy, curriculum, and instruction for English language learners. Bilingual Research Journal, 30(2), 521-546.

Miles, M., \& Huberman, M. (2000). Métodos para el manejo y el análisis de datos. In C. Denman \& J. Haro (Eds.), Por los rincones: Antología de métodos cualitativos en la investigación social (pp. 253 301). El Colegio de Sonora.

Moll, L., (1994). Literacy research in community and classrooms: A sociocultural approach. In B. Robert, M. P. Ruddell, \& H. Singer (Eds.). Theoretical models and processes of reading ( $4^{\text {th }} \mathrm{ed}$.) (pp. 179-207). Newark.

Rossman, G. B., \& Rallis, S. F. (2003). Learning in the field: An introduction to qualitative research. Sage Publications.

Sharkey, J., Clavijo, A., \& Ramírez, M. (2016). Developing a deeper understanding of Communitybased pedagogies with teachers in Colombia. Journal of Teacher Education, 67(4), 306-319.

Short, K., \& Burke, C. (1991). Creating curriculum: Teachers and students as a community of learners. Heinemann Educational Publishers.

Usma Wilches, J. (2009). Education and language policy in Colombia: Exploring processes of inclusion, exclusion, and stratification in times of global reform. Profile: Issues in Teachers Professional Development, 11(1), 123-141. 
Jhooni Quintero-González,

Amparo Clavijo-Olarte

Vasquez, V., \& Janks, H., \& Comber, B. (2019). Critical literacy as a way of being and doing. Language Arts, 96(2), 300-311.

Walqui, A. (2006). Scaffolding instruction for English language learners: A conceptual framework. International Journal of Bilingual Education and Bilingualism, 9(2), 159-80.

Walsh, M. (2010). Multimodal literacy: What does it mean for classroom practice? Australian Journal of language and literacy, 33(3), 211-239. 
Appendix A.

Students' PowerPoint Presentations

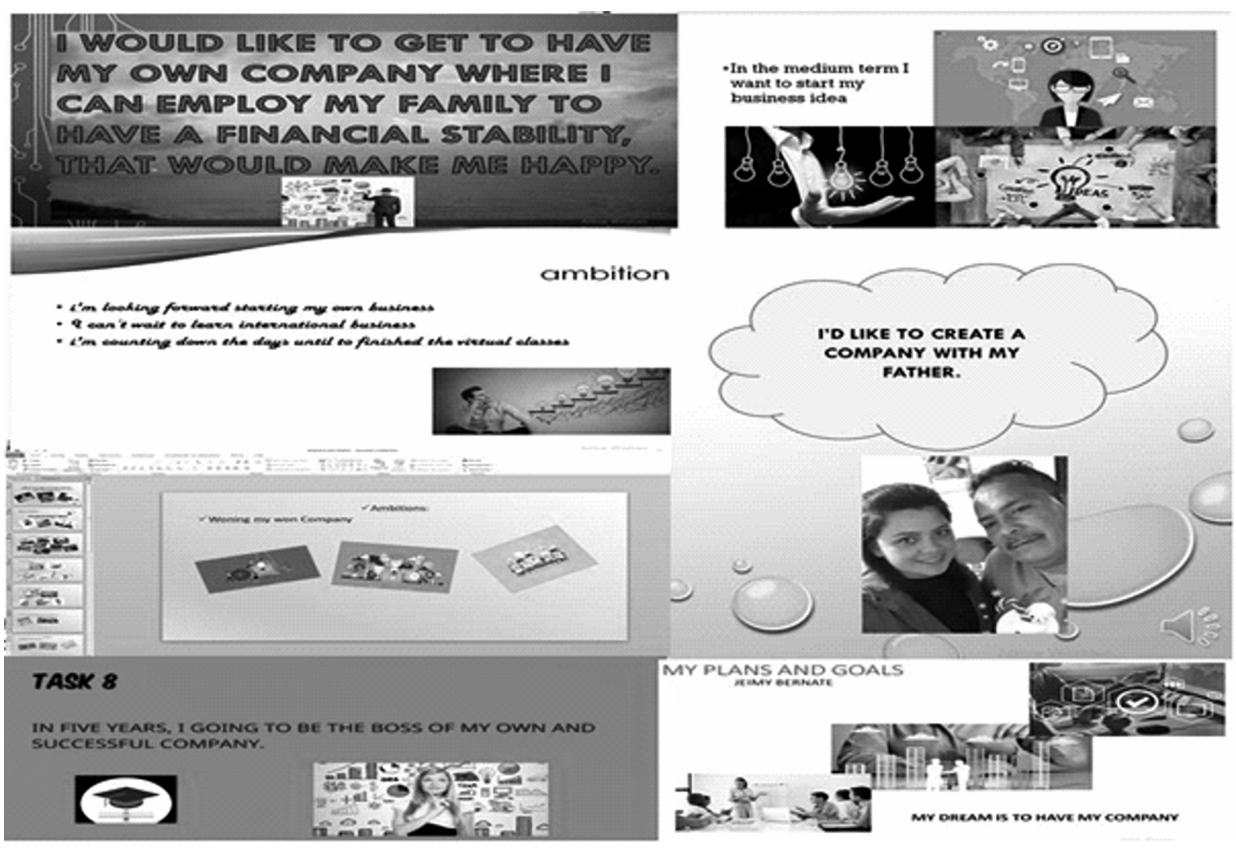


Jhooni Quintero-González,

Amparo Clavijo-Olarte

Appendix B.

Students' evidence and poster (Stock App).

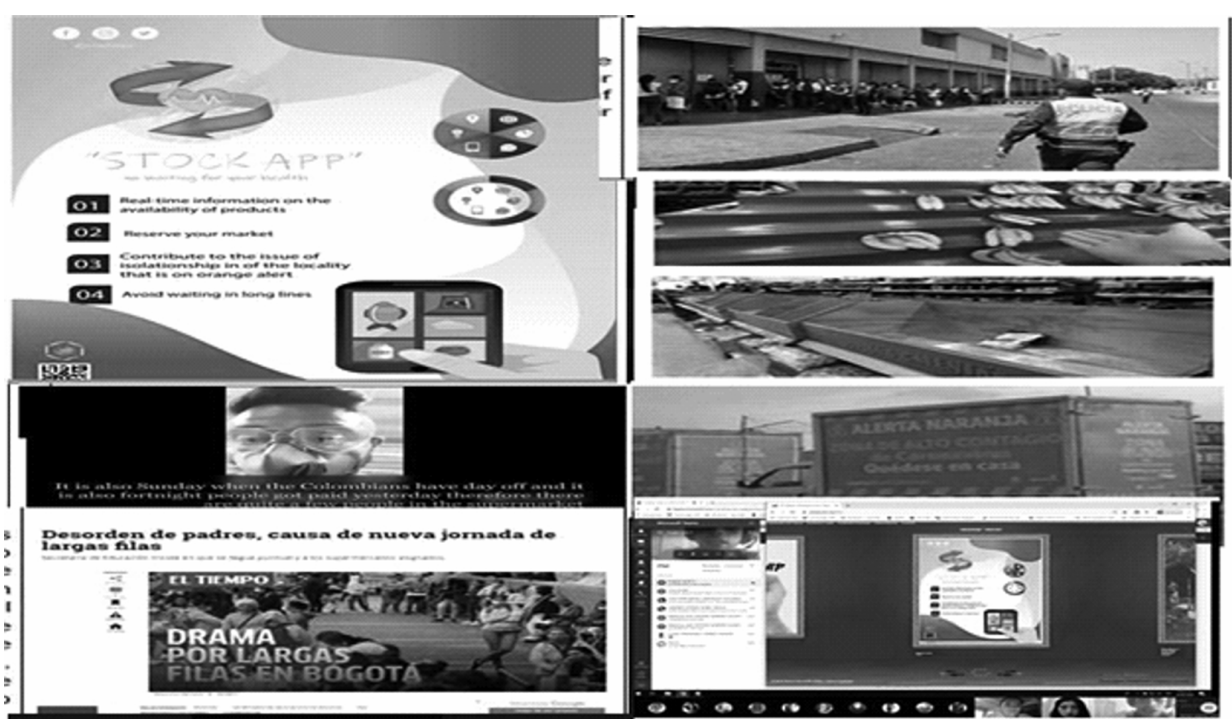




\section{Appendix C.}

Students' evidence and poster (Mader App).

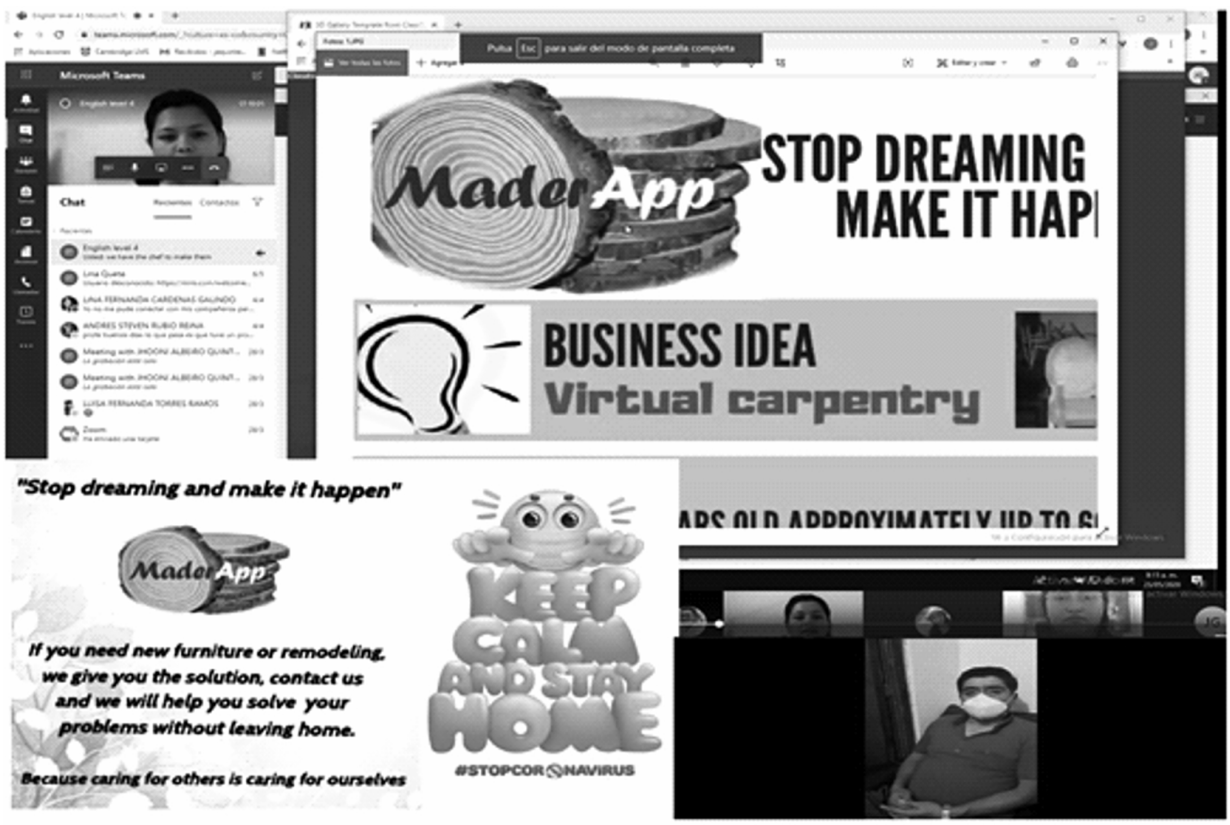


Jhooni Quintero-González, Amparo Clavijo-Olarte

\author{
Appendix D. \\ Students' evidence and poster (Vives Coffee).
}
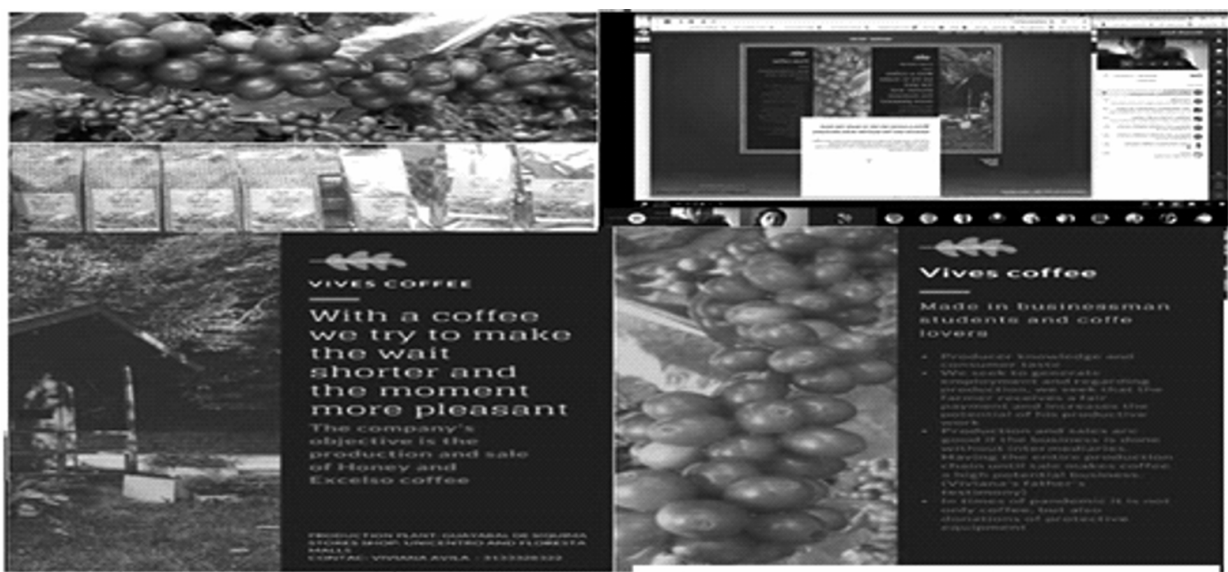

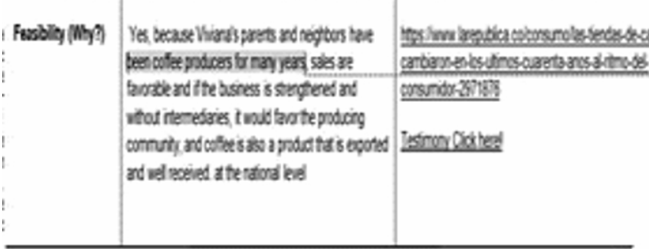

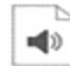

Audio

opinion

lardships with coffee harvest and merchants:- 
Appendix E.

Students' evidence and poster (Pet Store).
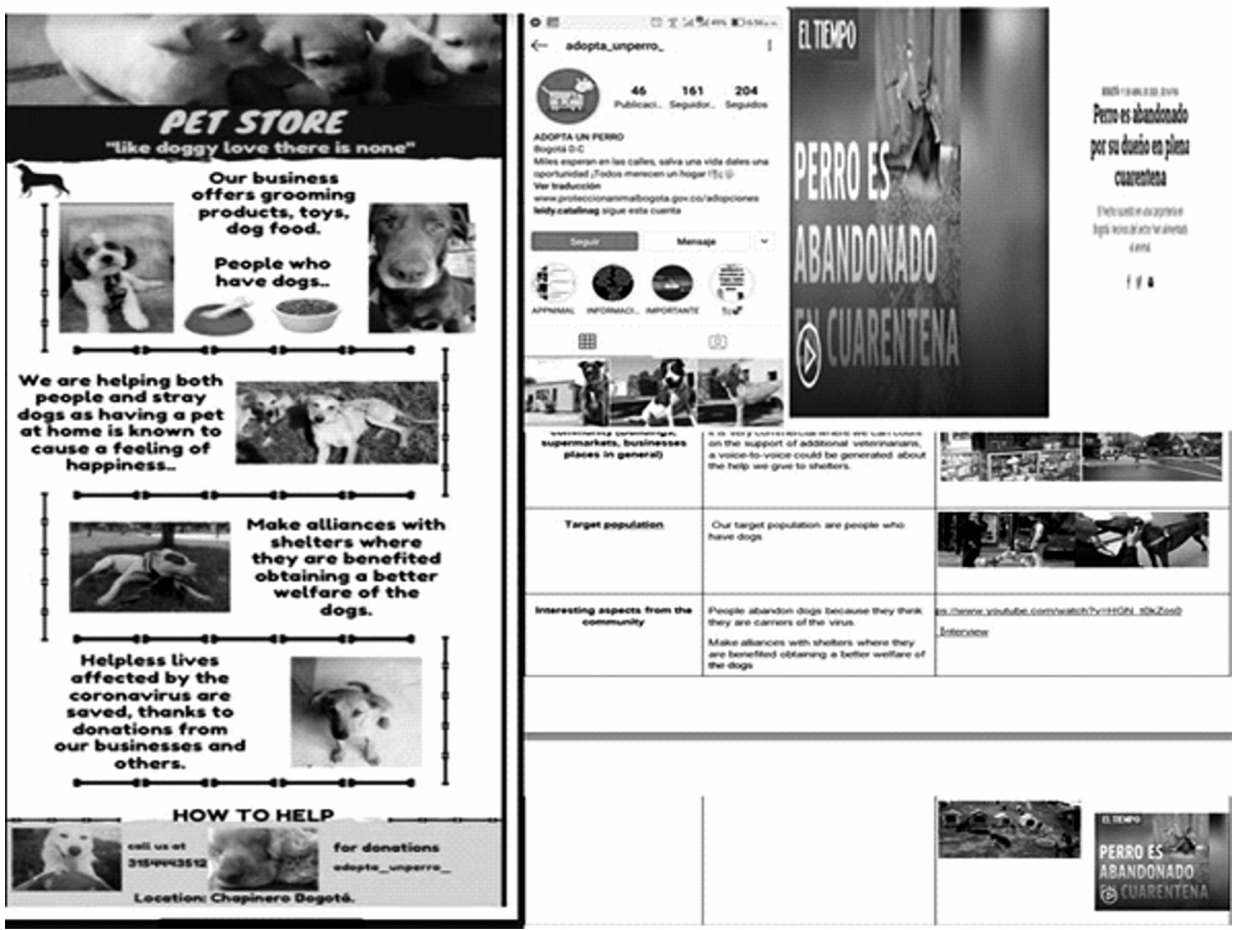
Jhooni Quintero-González,

Amparo Clavijo-Olarte

Appendix F.
Students' evidence and poster (Hakuna Matata).

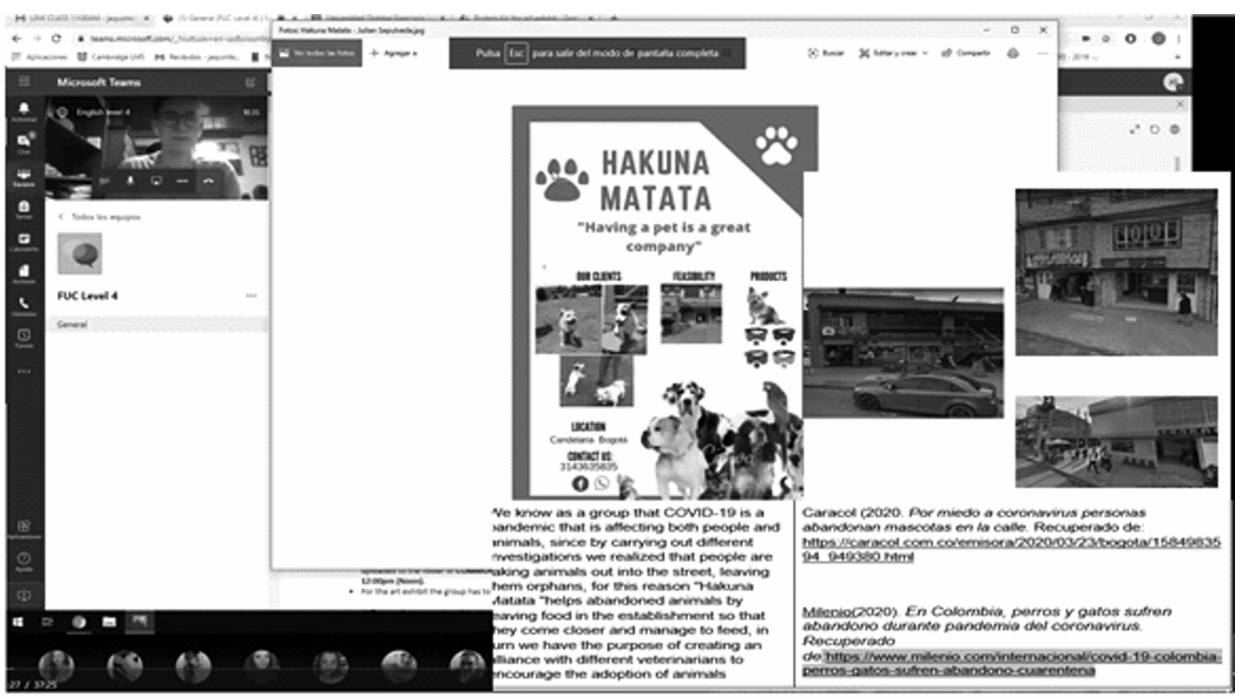




\section{Appendix G. Survey answers by students.}

\footnotetext{
¿Considera usted que el proyecto aportó a su carrera profesional? Justifique su respuesta.

26 respuestas

Sí, porque quiero tener mi propio negocio ya tendría como una idea para desarrollar.

Sí, pues ya anteriormente se había manejado actividades diferentes, y esta realmente fue un complemento.

Sí, el proyecto ayudó en mi carrera profesional porque adicional de indagar de otra forma y aspectos el proyecto que tenemos en mente con mi compañera nos ayudó a mejorar nuestro vocabulario.

Dí, el hecho de pensar en una idea de negocio nos ayuda a plantearnos preguntas de como iniciar nuestra propia idea de negocio.

Sí, como mencioné anteriormente, en ningún otro curso de inglés se había propuesto trabajar temas más corporativas como es el lenguaje de todo este ámbito empresarial.

Bueno, simplemente con la oportunidad de expresar una idea, es un gran avance en el desarrollo profesional, así que pienso que si fue muy útil.

Sí, la carrera que se cursa requiere de este tipo de ejercicios en los cuales podamos empezar a crear "empresa" y darnos cuenta de lo que esto requiere.
}

Aparte del aspecto profesional, ¿¿cree usted que le aportó en otro ámbito? Justifique su respuesta. 26 respuestas

Personal, ya que para la obtención de resultados se requiere de las relaciones personas. Entonces pues fortalece mucho esa parte y le da la comunicación.

Desarrollo de habilidades cognitivas, es una manera de entender otra cultura.

Sí, se dio aporte a muchos términos que sirve para cualquier ámbito.

Personal, ya que muchos de los aspectos realizados y vistos en el proyecto nos hace ver el lado perseverante de las cosas.

Tengo que desarrollar más mi comunicación social y ésto me ha ayudado,

Sí, porque es bueno tener en cuenta unos aspectos de la oportunidad se más solidario con las personas y no solo pensar en uno mismo.

Sí, quizás a tomar la decisión de implantar el negocio a futuro, asimismo contribuyó un poco en mi aprendizaje de inglés.

Durante el desarrollo del proyecto, ¿̨cree usted haber desarrollado habilidades en el idioma inglés? Justifique su respuesta.

26 respuestas

Aprendí vocabulario, y me exigí en la pronunciación ya que me cuesta muchos

Sí, porque aprendí nuevas palabras y en especial en cuanto a la pronunciación considero que reformé y habla y logré conocer palabras nuevas, así como su pronunciación.

Sí, pero también soy consciente de que el idioma debo practicarlo con mucha más frecuencia.Sí, me ayuda a pronunciar mejor el inglés además de aprender vocabulario.

Sí, aprendí nuevs palabras y conceptos para manejar en lo que se trascurrió de la materia.

Sí, con cada tema en el que se avanza, se va aprendiendo terminología y temas de interés para entablar una conversación.

sí, sobre todo en la parte de escucha ya que al estar atenta a mis compañeros se podía afianzar la habilidad de "escucha" del idioma. 